\title{
Biochemical profile, non-enzymatic antioxidants and functional attributes of raw and thermally processed West African Mud Creeper, Tympanotonos fuscatus var radula (Linnaeus, 1758)
}

\author{
Rasheed Olatunji Moruf* (D)
}

\begin{abstract}
Background: One of the many relevant factors that influence mollusc consumption is the quality of its meat. The meat of Tympanotonos fuscatus var radula has been traditionally used as a subsistence food source with high-quality nutritious culinary delicacy. The study assessed the biochemical profile, non-enzymatic antioxidants and functional attributes of T. fuscatus var radula from a brackish Creek in Southwest Nigeria.

Results: Protein formed the highest percentage both in raw and steamed samples with the mean values of $47.61 \mathrm{~g} / 100 \mathrm{~g}$ and $46.04 \mathrm{~g} / 100 \mathrm{~g}$ respectively. The total mineral content was higher in raw sample $\left(237.40 \mathrm{mg}^{\left.100 \mathrm{~g}^{-1}\right)}\right.$ than in steamed sample $\left(201.05 \mathrm{mg} 100 \mathrm{~g}^{-1}\right)$, in the decreasing order of phosphorus > sodium > calcium > potassium $>$ magnesium. Raw sample had the highest proportion of energy contribution, which was from protein $(P E P=53.1 \%)$, while the least energy contribution was from fat $(P E F=3.1 \%)$ in steamed sample. The cholesterol content of raw T. fuscatus var radula was $0.15 \pm 0.01 \mathrm{mg} / 100 \mathrm{~g}$, being reduced by steaming to $0.12 \pm 0.02 \mathrm{mg} / 100 \mathrm{~g}$, while a nonsignificantly lower percentage of oleic was also observed in steamed sample $(0.98 \pm 0.01 \%)$. After steaming, the values of TBA, ascorbic acid and DPPH increased from 0.22 to $1.41 \mathrm{mg} / 100 \mathrm{~g}, 15.31$ to $20.54 \mathrm{mg} / 100 \mathrm{~g}$ and 65.11 to $84.6 \%$, respectively. Relatively, higher mean values of water absorption capacity (198.13\%), oil absorption capacity (292.59\%), and foam capacity (6.90\%) were recorded in raw sample, while steamed sample was better in foam stability (33.33\%) and emulsion stability (51.51\%).
\end{abstract}

Conclusions: T. fuscatus var radula is a good source of nutrition, rich in protein and because of its good functional physiognomies, the steamed edible part will be highly desirable for preparing complimentary food.

Keywords: Antioxidant, Chemical composition, Gastropod, Shellfish, Nigeria

\section{Background}

Molluscs are important aquatic food resources, which add substantial economic value to the fisheries of the world. Bivalves and cephalopods contribute to the majority of molluscan fishery, with gastropods contributing

\footnotetext{
*Correspondence: tunjimoruf@gmail.com
}

Department of Fisheries and Aquaculture, Bayero University, Kano, Nigeria less than $2 \%$ of the total production (FAO 2015; Moruf et al. 2020a), although some gastropods are of relatively high economic value (Ab Lah et al. 2017). As the human population rises, demand for global fisheries products, including molluscs, increases every year, leading to the exploitation of new stocks (Dey 2015). Consequently, the existing mollusc catch needs to be augmented with underutilized species (Ab Lah et al. 2017). 
The West African Mud Creeper, Tympanotonos fuscatus var radula (Linnaeus, 1758) is a univalve gastropod of the Phylum Mollusca and the only existing species in the genus Tympanotonos (Reid et al. 2008). Its shell is much harder and stronger than that of a typical snail's shell. It is also regarded as a prosobranch periwinkle and commonly found in many brackish water creeks, estuaries and mangrove swamps within the Lagos Lagoon, Nigeria (Moruf and Lawal-Are 2015). Periwinkles are unique and important marine invertebrates that are used as dietary supplements. One of the many relevant factors that influence shellfish consumption is the quality of the meats (Moruf et al. 2020b). The meat of T. fuscatus var radula has been traditionally used as a subsistence food source with high-quality nutritious culinary delicacy. Nigerian periwinkle, for example, is used to make some delicacies, such as Edikang Ikong, Okoro Soup, and Afang Soup. This tasty mollusk has many health benefits and is sumptuous to behold.

Functional characteristics are intrinsic physicochemical physiognomies, which influence the behavior of properties in food systems during processing, manufacturing, storage and preparation (Eltayeb et al. 2011). Gelation, water and fat absorption capacities, emulsion capability and stability are important functional properties essential for food ingredients. Proteins solubility, foam capacity, foam stability, bulk density, and organoleptic properties are other key functionalities (Lawal-Are et al. 2020). Nigerians have started using periwinkle as a commercial meat, though the utilization is yet limited with a little scientific information about the nutritional status of the gastropod (Moruf and Akinjogunla 2018). In that light, the main objective of this study is to evaluate the biochemical compositions, non-enzymatic antioxidant status and functional attribute of the raw and cooked edible portion of West African Mud Creeper, T. fuscatus var radula (raw and steamed) collected from Abule-Agege Creek in Lagos State, Nigeria.

\section{Methods}

\section{Collection and preparation of specimens}

Samples of the West African Mud Creeper, T. fuscatus var radula (Linnaeus, 1758) were collected by scooping from the waterbed at low tides from the Abule-Agege Creek in Southwest Nigeria, between January and December 2019. The site lies between latitudes $6^{\circ} 26^{\prime}-37^{\prime} \mathrm{N}$ and longitude $3^{\circ} 23^{\prime}-4^{\circ} 20^{\prime} \mathrm{E}$ (Moruf et al. 2018). The shores of the creek are lined in undeveloped areas by mangrove swamps. An elaborate description of the study area was provided by Moruf and Ojetayo (2017).

To extract adhering sediments and organic particles, fresh samples were washed with purified water several times. The samples were transported in a $10-\mathrm{L}$ bucket to the laboratory and processed within $4 \mathrm{~h}$ of the collection. Using a bench vice, the shell was split and the viscera removed. The edible parts were used for all analyses. These samples were divided into two groups, with 10 samples of muscles in each group, with mean flesh weight of $2.76 \pm 1.05 \mathrm{~g}$. The first group (raw sample) was dried directly in the oven at $70{ }^{\circ} \mathrm{C}$ for $48 \mathrm{~h}$ and the second group was cooked in $200 \mathrm{ml}$ of distilled water for around 60 min by steaming using an automatic cooker $(2000 \mathrm{~W}$, Tefal, Zahran). At $70{ }^{\circ} \mathrm{C}$, the steamed samples were also dried for $48 \mathrm{~h}$. All dried specimens were weighed using a digital balance and homogenized using a kitchen blender.

\section{Laboratory analysis \\ Determination of biochemical profiles}

According to the methods of AOAC (2000), water content, crude protein, crude fat, crude fiber, ash, and carbohydrate content were determined. By means of the already confirmed amount of proteins and fat, the energy content of the edible part of the organism was calculated. The energy values $(\mathrm{KJ} / 100 \mathrm{~g})$ of the specimen were estimated, multiplying the amount of proteins (\%) by factor 17.16 and multiplying the amount of fat (\%) by factor 38.96 and then calculating the number of the two already determined values (Saveski et al. 2017).

Using a flame photometer (model 405, Corning, UK), some macro minerals (sodium and potassium) were determined, while other minerals were determined by the Atomic Absorption Spectrophotometer (Perkin \& Elmer model 403, USA) as defined by Gokoglu and Yerlikaya (2003). Mineral Safety Index was calculated from Eq. 1 as:

$$
\text { MSI }=[\text { TMSI (Standard) } / \text { RAI }] . R r,
$$

where MSI-Mineral Safety Index; TMSI-Tabulated MSI; RAI-Recommended Adult Intake; and $\mathrm{Rr}-$ Researh results.

Using Liebermann-Burchard reagents, the cholesterol content was measured. The Liebermann-Burchard reagent was prepared with $2 \mathrm{ml}$ of glacial acetic acid and $0.2 \mathrm{~mL}$ of concentrated sulfuric acid and then coated with aluminum foil. The chemicals were purchased from a commercial source (Fisher Scientific, USA) and used as received. Gas chromatography of methyl esters was used to separate and determine the volatile content of fat derived from samples (AOAC 2000). The GC analyses were performed on 7890A gas chromatography system (Agilent Technologies, California, USA) equipped with flame ionization detector and splitless injector $(1 \mu \mathrm{L})$. Injector and detector temperature were set at $270{ }^{\circ} \mathrm{C}$ and $280{ }^{\circ} \mathrm{C}$, respectively. In the determination of free fatty acid (FFA) as Oleic, one (1) g of the test sample was poured into a conical flask with $20 \mathrm{ml}$ of solvent 
mixture $(1: 1 \mathrm{v} / \mathrm{v}$ ethanol: diethyl ether) and $0.2 \mathrm{ml}$ of phenolphthalein indicator solution. The mixture was then titrated until the pink color appears and persists for at least $10 \mathrm{~s}$ when shaking with $0.1 \mathrm{~N} \mathrm{KOH}$. The \% FFA was calculated from Eq. 2 as:

$$
\% \mathrm{FFA}(\text { as Oleic Acid })=\frac{(V-B) \times N \times 28.21}{W}
$$

where $V$ volume of titrant (KOH) consumed for sample, $B$ volume of titrant consumed for blank, $N$ normality of titrant $(\mathrm{KOH}), W$ weight of sample.

\section{Determination of non-enzymatic antioxidants and functional properties}

Thiobarbituric acid (TBA) was colorimetrically determined in flesh samples of $T$. fuscatus var radula, as described by Torres Arreola et al. (2007). $10 \mathrm{~g}$ of minced flesh was macerated for 2 min with $50 \mathrm{ml}$ of distilled water, washed with $47.5 \mathrm{ml}$ of distilled water into a distillation flask with addition of $2.5 \mathrm{ml}$ of hydrochloric acid (4 N). A volume of $50 \mathrm{ml}$ distillate was collected from which $5 \mathrm{ml}$ of distillate was pipetted into a glass tube and mixed with $5 \mathrm{ml}$ of TBA reagent. After cooling the mixture, which was heated for $35 \mathrm{~min}$ in a boiling water bath, the optical density was measured against the blank at a wavelength of $538 \mathrm{~nm}$. A method based on the spectrometric quotation of the pink complex produced the after reaction of one malondialdhyde molecule (MDA) with two TBA molecules. The TBA was calculated from Eq. 3 as:

$$
\operatorname{TBA}(\text { Distillation })=\frac{C \cdot V}{\mathrm{Ms}}
$$

where $C$ is the concentration of MDA $(\pi \mathrm{M})$ as read from the calibration curve; $V$ is the volume of the distillate $(\mathrm{ml})$; and Ms is the mass of the sample (g).

By modifying a protocol described by Phenomenex (2011), the chromatographic method for evaluating ascorbic acid in fresh meat preparations was employed. 2,2-Diphenyl-1-(2,4,6-trinitrophenyl) hydrazyl (DPPH) was determined as described by Farvin et al. (2010), where in $20 \%$ ethanol, $2 \mathrm{~mL}$ of $0.1 \mathrm{mM} \mathrm{DPPH}$ was combined with $2 \mathrm{~mL}$ of $50 \mathrm{mg} / \mathrm{mL}$ sample concentration. By substituting samples with $2 \mathrm{~mL}$ of $6.25 \%$ ethanol, Blank was prepared. The sample was incubated with the blanks for $30 \mathrm{~min}$ in the dark. The absorbance was read at $520 \mathrm{~nm}$ using the JASCO UV-VIS spectrometer after the incubation time. The proportion of radical scavenging activity was calculated from Eq. 4 as:
With regard to functional properties, water absorption capacity (WAC) and oil absorption capacity (OAC) were determined following the method described by Brishti et al. (2017). The $0.25 \mathrm{~g}$ of specimen was mixed with $5 \mathrm{ml}$ distilled water or oil in pre-weighed centrifuge tube for $30 \mathrm{~s}$ using a vortex. Then, specimen was allowed to stand at room temperature $\left(20-25{ }^{\circ} \mathrm{C}\right)$ for $15 \mathrm{~min}$ and centrifuged at $3000 \mathrm{rpm}$ for $15 \mathrm{~min}$. After centrifugation, the supernatant was decanted, and the centrifuge tubes + precipitate were reweighed. The WAC and OAC were expressed as grams of water/oil absorbed per gram of the sample. The WAC and OAC were calculated by using the Eq. 5 as:

$$
\mathrm{WAC} \text { or } \mathrm{OAC}(\mathrm{g} / \mathrm{g})=\frac{W 2}{W 1}
$$

where $W 1=$ weight of the dry sample (g); $W 2=$ weight of precipitate + centrifuge tube $(\mathrm{g})$.

The modified methods reported by Souissi et al. (2007) were used to determine the emulsion stability. The foam formation and the foam stability were determined by optical measurements. The foams were produced with a homogenizer for $2 \mathrm{~min}$ at $17500 \mathrm{rpm}$, in $3 \mathrm{ml}$ of solution $(50 \mathrm{mM}$ Tris- $\mathrm{HCl}-0.5 \mathrm{M} \mathrm{NaCl}, \mathrm{pH}$ $7.5)$, which contained $1.5 \%$ protein. The initial height of the solution and the foam height were recorded at intervals of $0,2,10,20$ and $30 \mathrm{~min}$, using a caliper. The foaming capacity was expressed as the proportion of foam height at $0 \mathrm{~min}$ to solution height. The foaming stability (FS) was conveyed by the percentage of foam height at some time to $0 \mathrm{~min}$. The measurement of the height was rapid and accurate to three digits after the decimal point.

\section{Statistical analysis}

Data obtained was subjected to analysis of variance (ANOVA) using SPSS (Statistical Package for Social Sciences) version 24.0.0 statistical software. Statistically significant differences were identified at $p<0.05$.

\section{Results}

\section{Biochemical profile}

The proximate composition of T. fuscatus var radula is shown in Table 1. By steaming, the moisture content was reduced from $17.61 \mathrm{~g} / 100 \mathrm{~g}$ to $16.33 \mathrm{~g} / 100 \mathrm{~g}$. All the proximate contents were lower in the steamed samples than in the raw samples, with the exception of

$$
\text { Radical scavenging activity }(\%)=\frac{\text { A blank }- \text { A sample }}{\text { A blank }} \times 100
$$


carbohydrates $(24.10 \mathrm{~g} / 100 \mathrm{~g})$. A significant $(p<0.05)$ higher crude fiber content characterized the raw samples $(0.64 \pm 0.05 \mathrm{~g} / 100 \mathrm{~g})$. In crude fat and crude fiber, the values of the percent coefficient of variation (CV\%) were high, ranging from 84.67 to $99.94 \%$. The highest percentage proximate difference between raw and steamed samples (\%D) was recorded in crude fiber content with the value of $82.81 \%$.

The result of mineral content is contained in Table 2. The total macro element was higher in raw sample $\left(237.40 \mathrm{mg} 100 \mathrm{~g}^{-1}\right)$ than in steamed sample $(201.05 \mathrm{mg}$ $\left.100 \mathrm{~g}^{-1}\right)$. The highest percentage difference in mineral content between raw and steamed samples of T. fuscatus var radula was recorded in potassium with the value of $23.30 \%$. In raw samples, sodium $(56.2 \pm 0.62 \mathrm{mg} / 100 \mathrm{~g})$ and potassium $(37 \pm 0.07 \mathrm{mg} / 100 \mathrm{~g})$ were significantly higher $(p<0.05)$ than for steamed samples.

The various computed mineral ratios are contained in Table 3. Except for $\mathrm{Na} / \mathrm{K}$ and $\mathrm{Na} / \mathrm{Mg}$, all other ratios were comparably lower than the ideal value and acceptable range. Ideally, $\mathrm{Ca} / \mathrm{Mg}$ should be a 7.0:1 ratio of calcium relative to magnesium with a range of 3.0-11.0 being acceptable. The results of the study gave a ratio of 4.43-4.74, which is within the ideal range. In the raw to steamed samples, $\mathrm{Ca} / \mathrm{P}$ levels ranged between 1.52 and 1.55 . The $\mathrm{Na} / \mathrm{K}(2.50-2.53)$ and $\mathrm{Na} / \mathrm{Mg}(3.94-$ 4.17) ratios in the investigated samples fell within the optimal values of 2.4 and 4 , respectively, while the [K/ $(\mathrm{Ca}+\mathrm{Mg})](0.78-0.87)$ milliequivalent ratios were also lower than the reference balance of 2.2 .

Table 1 Percentage proximate composition in raw and steamed flesh of African Mud Creeper, T. fuscatus var radula

\begin{tabular}{lcclcccc}
\hline Proximate & Raw $(\mathbf{g} / \mathbf{1 0 0} \mathbf{~ g})$ & Steamed $(\mathbf{g} / \mathbf{1 0 0} \mathbf{g})$ & $\boldsymbol{p}$ value & SD & CV\% & D & \% D \\
\hline Moisture & $17.61 \pm 0.05$ & $16.33 \pm 0.07$ & 0.16 & 0.91 & 5.33 & 1.28 & 7.27 \\
Protein & $47.61 \pm 0.01$ & $46.04 \pm 0.01$ & 0.19 & 1.11 & 2.37 & 1.57 & 3.3 \\
Crude fat & $4.86 \pm 0.77$ & $1.22 \pm 0.09$ & 0.09 & 2.57 & 84.67 & 3.64 & 74.9 \\
Crude fiber & $0.64 \pm 0.05$ & $0.11 \pm 0.07$ & $0.04^{*}$ & 0.37 & 99.94 & 0.53 & 82.81 \\
Total ash & $12.95 \pm 0.01$ & $12.20 \pm 0.05$ & 0.25 & 0.53 & 4.22 & 0.75 & 5.79 \\
Carbohydrate & $16.33 \pm 0.61$ & $24.10 \pm 0.57$ & 0.08 & 5.49 & 27.18 & -7.77 & -47.58 \\
\hline
\end{tabular}

Standard deviation (SD), coefficient of variation per cent (CV \%), difference between raw and cooked (D), percentage difference (D). $p<0.05$ indicate significant difference

*significant difference

Table 2 Mineral content of raw and steamed flesh of African Mud Creeper, T. fuscatus var radula

\begin{tabular}{|c|c|c|c|c|c|c|c|}
\hline Mineral & Raw (mg/100 g) & Steamed (mg/100 g) & $p$ value & SD & CV\% & D & $\% \mathrm{D}$ \\
\hline Calcium & $43.14 \pm 0.05$ & $40.48 \pm 0.03$ & 0.08 & 1.88 & 4.5 & 2.66 & 6.17 \\
\hline Phosphorus & $83.33 \pm 0.32$ & $74.1 \pm 0.11$ & 0.11 & 6.53 & 8.29 & 9.23 & 11.08 \\
\hline Magnesium & $17.73 \pm 0.31$ & $14.75 \pm 0.22$ & 0.10 & 2.11 & 12.98 & 2.98 & 16.81 \\
\hline Sodium & $56.2 \pm 0.62$ & $43.34 \pm 0.71$ & $0.02^{*}$ & 9.09 & 18.27 & 12.86 & 22.88 \\
\hline Potassium & $37 \pm 0.07$ & $28.38 \pm 0.15$ & $0.00^{*}$ & 6.1 & 18.65 & 8.62 & 23.3 \\
\hline Total & 237.4 & 201.05 & & 25.7 & 11.72 & 36.35 & 15.31 \\
\hline
\end{tabular}

Standard deviation (SD), coefficient of variation per cent (CV \%), difference between raw and cooked (D), percentage difference (D)

*significant difference

Table 3 Mineral ratio in raw and steamed flesh of African Mud Creeper, T. fuscatus var radula

\begin{tabular}{llllllrr}
\hline Parameter & (Ref. balance) Ideal & $\begin{array}{l}\text { Acceptable ideal } \\
\text { range }\end{array}$ & Raw & Steamed & Mean & SD & CV\% \\
\hline $\mathrm{Ca} / \mathrm{Mg}$ & 7 & $3-11$ & 4.43 & 4.74 & 2.59 & 0.22 & 8.50 \\
$\mathrm{Ca} / \mathrm{P}$ & 2.6 & $1.5-3.6$ & 1.52 & 1.55 & 0.53 & 0.02 & 3.80 \\
$\mathrm{Ca} / \mathrm{K}$ & 4.2 & $2.2-6.2$ & 1.17 & 1.43 & 1.30 & 0.18 & 14.21 \\
$\mathrm{Na} / \mathrm{K}$ & 2.4 & $1.4-3.4$ & 2.50 & 2.53 & 1.52 & 0.01 & 0.38 \\
$\mathrm{Na} / \mathrm{Mg}$ & 4 & $2-6$ & 4.17 & 3.94 & 3.05 & 0.16 & 5.36 \\
{$[\mathrm{~K} /(\mathrm{Ca}+\mathrm{Mg})]$} & 2.2 & & 0.87 & 0.78 & 0.83 & 0.06 & 7.71 \\
\hline
\end{tabular}

Standard deviation (SD), Coefficient of variation per cent (CV\%) 
Table 4 Mineral safety index of raw and steamed flesh of African Mud Creeper, T. fuscatus var radula

\begin{tabular}{|c|c|c|c|c|c|c|c|c|c|c|c|}
\hline \multirow[t]{2}{*}{ Mineral } & \multirow[t]{2}{*}{ RAI (mg) } & \multirow[t]{2}{*}{ MSItv } & \multicolumn{3}{|l|}{ Raw } & \multicolumn{3}{|c|}{ Steamed } & \multirow[t]{2}{*}{ Mean } & \multirow[t]{2}{*}{ SD } & \multirow[t]{2}{*}{ CV\% } \\
\hline & & & MSIcv & D & $\% \mathrm{D}$ & MSIcv & D & $\% \mathrm{D}$ & & & \\
\hline $\mathrm{Ca}$ & 1200 & 10 & 0.36 & 9.64 & 96.41 & 0.34 & 9.66 & 96.63 & 0.35 & 0.02 & 4.5 \\
\hline $\mathrm{Mg}$ & 400 & 15 & 0.66 & 14.34 & 95.57 & 0.55 & 14.45 & 96.31 & 0.61 & 0.08 & 12.98 \\
\hline P & 1200 & 10 & 0.69 & 9.31 & 93.06 & 0.62 & 9.38 & 93.83 & 0.66 & 0.05 & 8.29 \\
\hline $\mathrm{Na}$ & 500 & 4.8 & 0.54 & 4.26 & 88.76 & 0.42 & 4.38 & 91.33 & 0.48 & 0.09 & 18.27 \\
\hline
\end{tabular}

Recommended adult intake (RAI), MSI Table value (MSItv), MSI calculated value (MSIcv), Difference between MSItv and MSIcv (D), Percentage difference (\%D), Standard deviation (SD), Coefficient of variation percent (CV\%)

Table 5 Energy value contributed by nutrients in raw and steamed African Mud Creeper,T. fuscatus var radula

\begin{tabular}{|c|c|c|c|c|c|c|}
\hline Parameter & Unit & Raw & Steamed & Mean & SD & CV\% \\
\hline \multirow[t]{2}{*}{ Total energy $\mathrm{E}$} & $\mathrm{kJ} 100 \mathrm{~g}^{-1}$ & 1267 & 1238 & 1252.16 & 20.70 & 1.65 \\
\hline & kcal $100 \mathrm{~g}^{-1}$ & 300 & 292 & 295.52 & 5.63 & 1.90 \\
\hline \multirow[t]{2}{*}{ PEF } & $\%\left(\mathrm{~kJ} 100 \mathrm{~g}^{-1}\right)$ & $11.8(180)$ & $3(45)$ & 7.4 & 6.22 & 84.09 \\
\hline & $\%$ kcal $100 \mathrm{~g}^{-1}$ & $12.1(44)$ & $3.1(11)$ & 7.6 & 6.36 & 83.74 \\
\hline \multirow[t]{2}{*}{ PEC } & $\%\left(\mathrm{~kJ} 100 \mathrm{~g}^{-1}\right)$ & $18.2(278)$ & $27.4(410)$ & 22.8 & 6.51 & 28.53 \\
\hline & $\%$ kcal $100 \mathrm{~g}^{-1}$ & $18(65)$ & $27.2(96)$ & 22.6 & 6.51 & 28.78 \\
\hline \multirow[t]{2}{*}{ PEP } & $\%\left(\mathrm{~kJ} 100 \mathrm{~g}^{-1}\right)$ & $53.1(809)$ & $52.3(783)$ & 52.7 & 0.57 & 1.07 \\
\hline & $\%$ kcal $100 \mathrm{~g}^{-1}$ & $52.6(190)$ & $51.9(184)$ & 52.25 & 0.49 & 0.95 \\
\hline \multirow[t]{2}{*}{ UEDP\% } & $\mathrm{kJ}$ & 31.86 & 31.37 & 31.62 & 0.35 & 1.1 \\
\hline & kcal & 31.56 & 31.13 & 31.35 & 0.3 & 0.97 \\
\hline
\end{tabular}

Total energy (TE), proportion of total energy due to fat (PEF), proportion of total energy due to carbohydrate (PEC), proportion of total energy due to protein(PEP), utilization of energy value due to protein (UEDP\%), standard deviation (SD), coefficient of variation per cent (CV\%)

The mineral safety index values are depicted in Table 4 . The standard minerals safely index (MSItv) for the minerals are $\mathrm{Ca}(10), \mathrm{Mg}(15), \mathrm{P}(10)$, and $\mathrm{Na}(4.8)$.

\section{Energy value contributed by nutrients}

Table 5 shows the results of the percentage energy contribution by nutrients. Total metabolisable energy ranged between 1497 and $1524 \mathrm{~kJ}_{100 \mathrm{~g}^{-1}}$ (355$\left.362 \mathrm{kcal} 100 \mathrm{~g}^{-1}\right)$. The highest proportion of energy contrition was from protein $(\mathrm{PEP}=53.1 \%)$ in raw sample, while the least energy contribution was from fat $(\mathrm{PEF}=3.1 \%)$ in steamed sample. The range of PEF \% was 3-11.8 while utilizable energy due to protein (UEDP \%) (assuming $60 \%$ of protein energy utilization) was similar in both raw $(3.86 \mathrm{~kJ} / 3.56 \mathrm{kcal})$ and steamed samples $(31.37 \mathrm{~kJ} / 3.13 \mathrm{kcal})$.

\section{Cholesterol and free fatty acid contents}

The cholesterol content of raw T. fuscatus var radula was $0.15 \pm 0.01 \mathrm{mg} / 100 \mathrm{~g}$, being reduced by steaming to $0.12 \pm 0.02 \mathrm{mg} / 100 \mathrm{~g}$ (Fig. 1), while a nonsignificantly lower percentage of oleic was also observed in steamed sample $(0.98 \pm 0.01 \%)$.

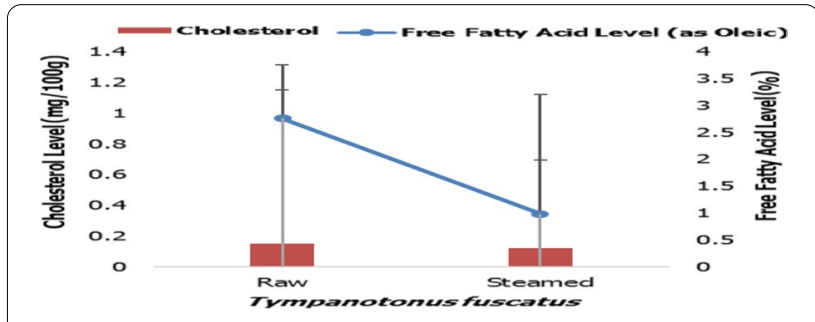

Fig. 1 Cholesterol and free fatty acid contents of raw and steamed edible part of T. fuscatus var radula

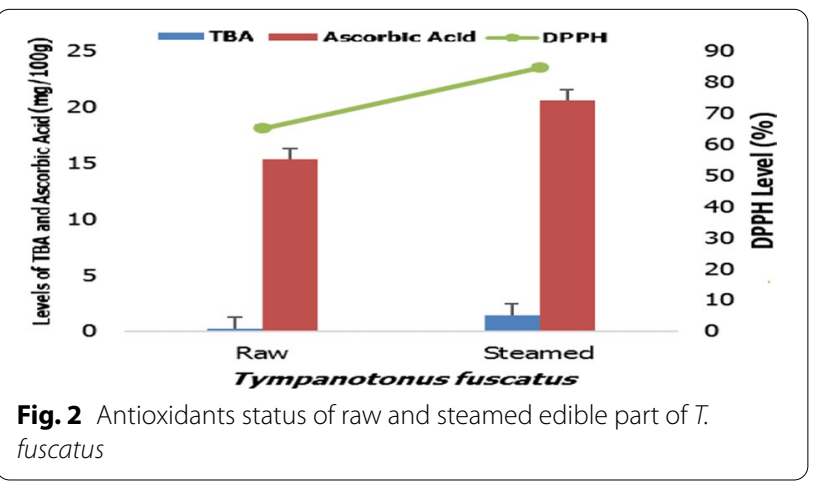




\section{Non-enzymatic antioxidants status}

The results of non-enzymatic antioxidants are reported in Fig. 2. After steaming, the values of TBA, ascorbic acid and DPPH increased from 0.22 to $1.41 \mathrm{mg} / 100 \mathrm{~g}$, 15.31 to $20.54 \mathrm{mg} / 100 \mathrm{~g}$, and 65.11 to $84.6 \%$, respectively. There was no significant difference in antioxidant status between raw and steamed flesh of T. fuscatus var radula., except for DPPH ( $p$ value $<0.05)$.

\section{Functional attributes}

The result of the functional properties of raw and cooked samples of T. fuscatus var radula is presented in Fig. 3. Relatively, higher mean values of water absorption capacity (198.13\%), oil absorption capacity (292.59\%), and foam capacity $(6.90 \%)$ were recorded in raw samples, while steamed sample was better in foam stability (33.33\%) and emulsion stability (51.51\%).

\section{Discussion}

The results indicate that all the proximate compositions were lower in the steamed samples than in the raw samples, with the exception of carbohydrates. The high carbohydrate content of steamed sample indicates that it could be used to manage protein-energy malnutrition. In crude fat and crude fiber, the $\mathrm{CV} \%$ were generally high, indicating heterogeneous relationships of these two proximate parameters for raw and steamed samples of T. fuscatus var radula. The proximate content both in raw and steamed samples is higher in values than that obtained in periwinkle meat from Onitcha, as reported by Ogungbenle and Omowole (2012). Moruf and Lawal-Are (2019), however, reported higher protein content, ranging from 51.90 to $68.92 \%$ for edible crabs of Nigeria coast.

Similarly, the results of macroelements concentration indicate a decreasing order of phosphorus $>$ sodium $>$ calcium $>$ potassium $>$ magnesium, across samples. LawalAre et al. (2018a) have reported a similar decreasing

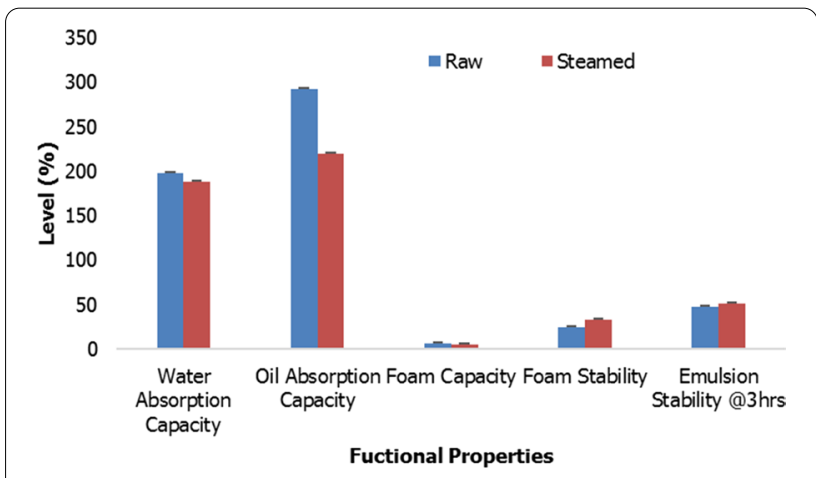

Fig. 3 Functional characteristic of raw and steamed edible part of $T$. fuscatus var radula order of mineral content for the whole and fillet of Guinean Mantis Shrimp, Squilla aculeata calmani. The level of both sodium and potassium in the raw samples was also higher than $55.53 \pm 20.97 \mathrm{mg} / 100 \mathrm{~g}$ of sodium and $33.33 \pm 1.76 \mathrm{mg} / 100 \mathrm{~g}$ of potassium, reported for the periwinkle from Abule-Eledu Creek (Moruf and Akinjogunla 2018). Sodium and potassium are essential in the regulation of $\mathrm{pH}$, osmotic pressure, acid-base balance, muscle and nerve irritability, control glucose absorption, and active transport of glucose/amino acids (Moruf et al. 2019; Lawal-Are et al. 2021a, b).

Mineral ratios revealed not only the significant balance between elements, according to Watts (2010), but also provide details on many factors that can be represented by a disruption of their relationships, such as disease states, physiological and developmental factors, dietary and drug effects. In the present study, $\mathrm{Ca} / \mathrm{Mg}$ indicates that the meat of $T$. fuscatus var radula can stand as the only source of calcium in a diet. Calcium and magnesium appear to have a synergistic relationship in the body. Each can affect both the absorption and excretion of the other. Magnesium deficiency alters cellular calcium levels in the animal system (Nadler et al. 2018). By consuming more magnesium, the negative calcium balance in the body may also be reversed (Kelly et al. 2018). The study of Rosanoff et al. (2016) has shown that $\mathrm{Ca} / \mathrm{Mg}$ ratio of approximately 2:1 is considered safe, whereas ratios below 2:1 can lead to heart disease. $\mathrm{Ca} / \mathrm{P}$ levels in the present study were much higher than 0.5 , the minimum standard for favorable absorption of $\mathrm{Ca}$ in the intestine and for the formation of bones (Adeyeye 2014). If the $\mathrm{Ca} / \mathrm{P}$ ratio is above 1.0, food is considered 'good' and 'bad' if the ratio is less than 0.5 (Adeyeye 2014; Moruf et al. 2021a). Because of the regulatory mechanisms which control calcium and phosphorus homeostasis within the body, $\mathrm{Ca}: \mathrm{P}$ is an important determinant of calcium absorption and retention (Loughrill et al. 2017). Common practice is to have a Ca:P molar ratio between 1:1 and 2:1, where a lower ratio may adversely affect calcium balance, which subsequently may increase the risk of bone fracture and osteoporosis (Koletzko et al. 2005). The interaction of sodium and potassium is integral to maintaining healthy blood. The $\mathrm{Na} / \mathrm{K}$ and $\mathrm{Na} / \mathrm{Mg}$ ratios in the investigated samples fell within the optimal values of 2.4 and 4, respectively. According to McDonough et al. (2017), raising dietary potassium to sodium ratio to recommended level helps reduce heart and kidney diseases. The $[\mathrm{K} /(\mathrm{Ca}+\mathrm{Mg})]$ milliequivalent ratios were also lower than the reference balance of 2.2. This is contrary to Adeyeye et al. (2017), who reported a higher milliequivalent ratio of $12.8: 1$ to $14.7: 1$ on the furs of some selected domestic animals.

In both the raw and steamed samples, all the measured minerals had MSI lower than the standard value, 
thus giving positive differences $\left(\mathrm{MSI}_{\text {Calculated }}<\mathrm{MSI}_{\text {Table}}\right)$. This implies that the body might not be overloaded with these minerals by $T$. fuscatus; thus avoiding the possibility of secondary hypertension (Ademola and Abioy 2017). This is in line with the report that $\mathrm{Ca}, \mathrm{P}$ and $\mathrm{Na}$ in the shell and flesh of Royal Spiny Lobster (Panulirus regius) would not constitute mineral overload to consumers (Moruf et al. 2021b).

In terms of energy value contributed by nutrients, the range of $\mathrm{PEF} \%$ in the present study was lower than recommended level of $30-35 \%$ for total fat energy intake (Adeyeye 2014), which is beneficial for people wishing to adopt the guidelines for a healthy diet. UEDP \% was similar in both raw and steamed samples while lower than the recommended safe level of $8 \%$ for an adult man who requires $55 \mathrm{~g}$ protein per day with $60 \%$ utilization (Adeyeye and Adubiaro 2018). This indicates that the protein concentration in African Mud Creeper in terms of energy would not be enough to prevent protein energy malnutrition in children and adults fed solely on the samples as main source of protein.

The results of cholesterol and free fatty acid contents indicate reductions by steaming. This disparity can be due to the fact that heating affects the food composition and chemical structure. The result agree well with Lawal-Are et al. (2018b), who reported $0.923 \pm 0.02 \mathrm{mg} / 100 \mathrm{~g}$ of raw cuttlefish cholesterol content, which was decreased by boiling $(0.711 \pm 0.02 \mathrm{mg} / 100 \mathrm{~g})$, but increased by frying $(1.037 \pm 0.02 \mathrm{mg} / 100 \mathrm{~g})$. Similarly, the results of non-enzymatic antioxidants correspond to the report of Wan Yusof et al. (2019) with nonsignificant differences in both male and female tissues of Scyla olivacea regarding its total phenolic content, DPPH, and superoxide dismutase activities.

Water absorbing capacity is influenced by $\mathrm{pH}$ and ionic strength (i.e. salt) reflecting the extent of denaturation of the protein (Butt and Rizwana 2010). The high oil absorption capacity, which acts as a flavour retainer and enhances the mouth feel of food, reveals that African Mud Creeper would be good samples for baking products better than cuttlefish with 197-220\% (Lawal-Are et al. 2018b). The African Mud Creeper in the present study had foam stability that remained uncollapsed after steaming; a quality of most commercial ingredients used to produce baking products such as cakes or toppings for whipping. The samples also had good emulsion stability, which will make them useful in products that depend on stable emulsion formation. The result is comparable with the emulsion stability value of $32.66 \pm 1.40 \%$ for boiled Smooth Swim Crab, Portunus validus (Lawal-Are et al. 2020). Generally, the variation in functional characteristics recorded in the present study according to the view of Lawal-Are et al. (2020), is a function of the ionogenic groups present in protein molecules in the lyophilic colloidal systems of protein solutions.

\section{Conclusion}

The study concluded that the edible muscles in T. fuscatus var radula contain a high protein and low fat content that are significantly associated with needed macro minerals. After steaming, the biochemical compositions were not greatly affected. The process of steaming facilitates the detachment of muscles from the shell and develops the organoleptic properties of cooked snail meat. Due to its good functional physiognomies, the steamed edible part will be highly desirable for preparing complimentary food.

\section{Abbreviations \\ AOAC: Association of Official Analytical Chemists..}

\section{Acknowledgements}

The author would like to thank Dr. (Mrs) Aderonke Omolara Lawal-Are, an Associate Prof. of the Department of Marine Sciences, University of Lagos, for the technical assistance provided in the study. The author would also like to acknowledge the editorial assistance given by Hajia Hawwau Moruf (CLN) of the Department of Library and Information Science, Federal University DutsinMa, Katsina State, Nigeria.

\section{Authors' contributions}

The single author is solely responsible to the design and implementation of the research, to the analysis of the results and to the writing of the manuscript. The author read and approved the final manuscript.

\section{Funding}

No funding was received from any agency or person to carry out this research.

Availability of data and materials

The data that support the findings of this study are available within this article.

\section{Declarations}

Ethics approval and consent to participate Not applicable.

\section{Consent for publication}

Not applicable.

\section{Competing interests}

The author reported no potential conflict of interest.

Received: 19 March 2021 Accepted: 3 May 2021

Published online: 13 May 2021

\footnotetext{
References

Ab Lah R, Smith J, Savins D, Dowell A, Bucher D, Benkendorff K (2017) Investigation of nutritional properties of three species of marine turban snails for human consumption. Food Sci Nutr 5(1):14-30

Ademola OA, Abioy MOR (2017) Proximate composition, mineral content and mineral safety index of Lablab purpureus seed flour. Int J Sci Healthc Res 2(4):44-50
} 
Adeyeye El (2014) Proximate, minerals and amino acids composition of Acanthurus monronviae and Lutjanus goreensis fish muscle. BMR Biotechnol $1(1): 1-21$

Adeyeye El, Adubiaro HO (2018) Proximate, mineral, vitamin compositions, mineral safety index and mineral ratios of the flesh of heterosexual pairs of Neopetrolisthes maculatus. Sustain Food Prod 46:1-17

Adeyeye El, Adesina AJ, Akinsola AF, Olagboye SA (2017) Comparative assessment of the proximate, mineral, vitamin compositions and mineral safety index of some selected domestic animals' furs. J Bio Inno 6(3):462-478

AOAC (2000) Official methods of analysis of the association of official analytical chemist, 14th edn. Washington, DC, USA

Brishti FH, Zarei M, Muhammad SKS, Ismail-Futry MR, Shukri R (2017) Evaluation of the functional properties of mung bean protein isolate for development of textured vegetable protein. Int Food Res J 24:1595-1605

Butt MS, Rizwana B (2010) Nutritional and functional properties of some promising legumes protein isolates. Pak J Nutr 9(4):373-379

Dey MM (2015) World and US demand and supply relationships for seafood: implications for aquaculture producers. Aquac Mag 41(2):44-45

Eltayeb ASM, Ali AO, Abou-Arab A, Abu-Salem FM (2011) Chemical composition and functional properties of flour and protein isolate extracted from Bambara groundnut (Vigna subterranean). Afr J Food Sci 5(2):82-90

FAO (2015) Fishery statistical collections: global capture production. Food and Agriculture Organization of the United Nations

Farvin KHS, Baron CP, Nielsen NS, Jacobsen C (2010) Antioxidant activity of yoghurt peptides: part 1-in vitro assays and evaluation in $\omega$-3 enriched milk. Food Chem 123:1081-1089

Gokoglu N, Yerlikaya P (2003) Determinaton of proximate composition and mineral contents of blue crab (Callinectes sapidus) and swim crab (Portunus pelagicus) caught off the Gulf of Antalya. Food Chem 80(4):495-498

Kelly O, Gilman J, llich J (2018) Utilizing dietary micronutrient ratios in nutritional research may be more informative than focusing on single nutrients. Nutrients 10(1):107

Koletzko B, Baker S, Cleghorn G, Neto UF, Gopalan S, Hernall O (2005) Global standard for the composition of infant formula: recommendations of an ESPGHAN coordinated international expert group. J Paediatr Gastroenterol Nutr 41:584-599

Lawal-Are AO, Moruf RO, Afolayan OA (2018a) Proximate composition, mineral profile and cholesterol level in whole and fillet of the Guinean Mantis Shrimp, Squilla aculeata calmani (Holthuis, 1959) (Crustacea: Stomatopoda). Albanian J Agric Sci 17(3):160-165

Lawal-Are AO, Moruf RO, Junaid DA, Oke MO (2018b) Chemical bio-compounds and functional properties of raw and processed cuttlefish, Sepia officinalis (Mollusca: Cephalopoda). Food Environ Saf 17(3):332-340

Lawal-Are AO, Moruf RO, Sanni MA, Chukwujindu CM (2020) Food Properties of minced and whole jumbo lump of the smooth swim crab, Portunus validus (Herklot, 1851). J Sci Res Dev 19(1):126-137

Lawal-Are AO, Moruf RO, Ojeah FL, Taiwo LO, Aligbeh OE (2021a) Weight yield factor, chemical composition and energy value in three imported shellfish species in Nigeria. Niger J Anim Prod 48(3):63-70

Lawal-Are AO, Moruf RO, Ojeah FL, Taiwo LO, Aligbeh OE (2021b) Weight yield factor, chemical composition and energy value in three imported shellfish species in Nigeria. Niger J Anim Prod 48(3):63-70

Loughrill E, Wray D, Christides T, Zand N (2017) Calcium to phosphorus ratio, essential elements and vitamin D content of infant foods in the UK: Possible implications for bone health. Matern Child Nutr 13(3):e12368

McDonough AA, Veiras LC, Guevara CA, Ralph D (2017) Cardiovascular benefits associated with higher dietary $\mathrm{K}+\mathrm{vs}$. lower dietary $\mathrm{Na}+$ : evidence from population and mechanistic studies. Am J Physiol Endocrinol Metab 312(4):348-356

Moruf RO, Akinjogunla VF (2018) Photometric determination of macro-micro minerals in the West African Mud Creeper, Tympanotonus fuscatus var radula (Linnaeus, 1758). J Exp Res 6(3):35-40

Moruf RO, Lawal-Are AO (2015) Growth pattern, whorl and girth relationship of the periwinkle, Tympanotonus fuscatus var radula (Linnaeus, 1758) from a tropical estuarine lagoon, Lagos, Nigeria. Int J Fish Aquat Stud 3(1):111-115

Moruf RO, Lawal-Are AO (2019) Protein, amino acid and fatty acid profiles of two edible crabs of Lagos coast, Nigeria. J Bangladesh Agric Univ 17(3):396-401

Moruf RO, Ojetayo TA (2017) Biology of the West African Fiddler Crab, Uca tangeri (Decapoda: Ocypodidae) from a Mangrove Wetland in Lagos, Nigeria. Int J Aquat Biol 5(4):263-267

Moruf RO, Bolaji OD, Lawal-Are AO (2018) Biometrics, gut contents and sexual dimorphism of the West African Mud Creeper, Tympanotonus fuscatus var radula from the mangrove swamps of a coastal estuary in Nigeria. Egypt $J$ Aquat Biol Fish 22(1):87-96

Moruf RO, Saba AO, Chukwu-Osazuwa J, Elegbede IO (2019) Seasonal variation in macro-micronutrient compositions of the flesh and shell of the Portunid Crab, Callinectes amnicola (De Rochebrune, 1883) from the coastal waters of Southwest Nigeria. Agricultura 102(1-2):200-209

Moruf HA, Ogunbambo MM, Moruf RO (2020a) The relevance of information of shellfish quality on consumers' purchase decision in Lagos metropolis, Nigeria. J Agric Econ Environ Soc Sci 6(1):71-79

Moruf RO, Okunade GF, Elegbeleye OW (2020b) Bivalve mariculture in twoway interaction with phytoplankton: a review of feeding mechanism and nutrient recycling. Bull UASVM Anim Sci Biotechnol 77(2):1-8

Moruf RO, Taiwo MA, Adebayo Q (2021a) Nutritional and functional attributes of raw and grilled crabmeat. Agric Sci Technol 13(1):18-28

Moruf RO, Afolayan OA, Taiwo MA, Ogunbambo MM (2021b) Estimation of nutritional energy values, mineral ratio and mineral safety index in the Royal Spiny Lobster, Panulirus regius (De Brito Capello, 1864). Croat J Food Sci Technol 13(1):18-23

Nadler JL, Buchanan T, Natarajan R, Antonipillai I, Bergman R, Rude R (2018) Magnesium deficiency produces insulin resistance and increased thromboxane synthesis. Hypertension 21:1024-1029

Ogungbenle HN, Omowole BM (2012) Chemical, functional and amino acid composition of periwinkle (Tympanotonus fuscatus var. radula) meat. Int J Pharm Sci Rev Res 13(2):128-132

Phenomenex. (2011) Inc. Chromatography product guide 11/12. Vitamin Mix on Luna HILIC, p 207

Reid DG, Dyal P, Lozouet P, Glaubrecht M, Williams ST (2008) Mud whelks and mangroves: the evolutionary history of an ecological association (Gastropoda: Potamididae). Mol Phylogenet Evol 47(2):680-699

Rosanoff A, Dai Q, Shapses SA (2016) Essential nutrient interactions: does low or suboptimal magnesium status interact with Vitamin D and/or Calcium Status? Adv Nutr Int Rev J 7(1):25-43

Saveski A, Kalevska T, Stamatovska V, Damjanovski D (2017) Chemical composition and energy value in the meat of the Macedonian and Ohrid trout. Food Environ Saf J 16(1):40-46

Souissi N, Bougatef A, Triki-Ellouz Y, Nasri M (2007) Biochemical and functional properties of sardinella (Sardinella aurita) by-product hydrolysates. Food Technol Biotechnol 45(2):187-194

Torres Arreola W, Soto Valdez H, Peralta E, Cardenas López JL, Ezquerra Brauer JM (2007) Effect of a low-density polyethylene film containing butylated hydroxytoluene on lipid oxidation and protein quality of Sierra fish (Scomberomorus sierra) muscle during frozen storage. J Agric Food Chem 55:6140-6146

Wan Yusof WR, Badruddin AF, Ahmad NM, Husaini ASA, Swamy M (2019) Proximate composition and antioxidant properties of Orange Mud Crab, Scylla olivacea. J Aquat Food Prod Technol 28(4):365-374

Watts DL (2010) HTMA mineral ratios. A brief discussion of their clinical importance. Trace Elem Newsl 21:1-3

\section{Publisher's Note}

Springer Nature remains neutral with regard to jurisdictional claims in published maps and institutional affiliations. 